\title{
Determinants of healthcare facility utilization for childbirth in Kuantan Singingi regency, Riau province, Indonesia 2017
}

Rajunitrigo Sukirman ${ }^{1,2}$, Tri Yunis Miko Wahyono ${ }^{1}$ and Siddharudha Shivalli ${ }^{3,4^{*}}$ (D)

\begin{abstract}
Background: Reducing maternal mortality ratio (MMR) is a high priority public health issue in developing countries such as Indonesia. The current MMR in Indonesia is 126/100,000 live births. Optimum use of available healthcare facilities for delivery can avert maternal deaths. This study aimed to determine the factors associated with healthcare facility utilization for childbirth in Kuantan Singingi regency, Riau province, Indonesia 2017.

Methods: We conducted a community-based cross-sectional study in 15 sub-districts of Kuantan Singingi regency from May-June 2017. We selected 320 mothers from 15 sub-districts who delivered in the last 3 months (FebruaryApril 2017). Trained data enumerators collected the relevant data by using a pre-tested semi-structured questionnaire. We used Cox regression analysis to determine the factors associated with delivery at healthcare facilities. Prevalence Ratio (PR) with a 95\% confidence interval (Cl) for childbirth at healthcare facilities was the key outcome measure.
\end{abstract}

Results: Only $54.4 \%$ (174) of the 320 mothers delivered at healthcare facilities. Knowledge about pregnancy danger signs ( $P R=1.59,95 \% \mathrm{Cl}: 1.15-2.2)$, attitude towards healthcare services ( $\mathrm{PR}=0.79,95 \% \mathrm{Cl}: 0.33-1.89)$, and access to health care services ( $\mathrm{PR}=0.39,95 \% \mathrm{Cl}: 0.18-0.84)$ were the dominant factors of childbirth at healthcare facilities. There was an interaction between attitude and access to healthcare influencing delivery at healthcare facilities.

Conclusions: Utilization of healthcare facilities for childbirth was low in Kuantan Singingi regency. Knowledge of pregnancy danger signs was an independent correlate of childbirth at healthcare facilities. Also, the interaction between attitude and access to healthcare showed a significant influence on childbirth at healthcare facilities. We recommend strengthening of existing maternal and child health program with a particular emphasis on complete and quality antenatal care, health education on danger signs of pregnancy and childbirth, and promoting positive attitudes towards healthcare facilities.

Keywords: Epidemiologic, Determinants, Delivery place, Healthcare facility, Indonesia

\footnotetext{
* Correspondence: shivalli.bhu@gmail.com

${ }^{3}$ Non-Communicable Diseases Regional Technical Advisor, Southeast Asia Regional Office (SEARO), TEPHINET, A Program of the Task Force for Global Health, Inc., Decatur, GA 30030, USA

${ }^{4}$ Department of Medical Statistics, London School of Hygiene \& Tropical Medicine, London WC1E 7HT, UK

Full list of author information is available at the end of the article
}

(c) The Author(s). 2020 Open Access This article is licensed under a Creative Commons Attribution 4.0 International License, which permits use, sharing, adaptation, distribution and reproduction in any medium or format, as long as you give appropriate credit to the original author(s) and the source, provide a link to the Creative Commons licence, and indicate if changes were made. The images or other third party material in this article are included in the article's Creative Commons licence, unless indicated otherwise in a credit line to the material. If material is not included in the article's Creative Commons licence and your intended use is not permitted by statutory regulation or exceeds the permitted use, you will need to obtain permission directly from the copyright holder. To view a copy of this licence, visit http://creativecommons.org/licenses/by/4.0/. The Creative Commons Public Domain Dedication waiver (http://creativecommons.org/publicdomain/zero/1.0/) applies to the data made available in this article, unless otherwise stated in a credit line to the data. 


\section{Background}

Reducing Maternal Mortality Ratio (MMR) is the biggest challenge in developing countries. In 2015, the estimated global MMR was 216 per 100,000 live births, with a total of 303,000 maternal deaths [1]. Approximately $99 \%$ of the global maternal deaths are reported from developing regions [2]. Sub-Saharan Africa and Southern Asia account for 66 and $22 \%$ of the global maternal deaths, respectively [2]. Indonesia, with an MMR of 126 per 100,000 live births (2010-15), is one of 39 countries that are categorized as making progress in reducing maternal deaths $[2,3]$. This figure is still far from the MMR target (70 per 1,00,000 live births) of Sustainable Development Goals (SDGs)-2030. Most of the maternal deaths are attributed to complications of childbirth [4]. In addition to maternal mortality, high neonatal mortality is seen in primiparous mothers with complications of childbirth [5]. Complications of childbirth occur due to delays in three phases (delays in seeking healthcare, reaching the healthcare facility, and in receiving adequate care at the point of service). Delivering at a health facility can be achieved by avoiding the first and second phases of these delays $[6,7]$.

In 2000, the government strengthened its strategy and intervention in reducing MMR through 'Making Pregnancy Safer' (MPS). MPS is one of the strategies focusing on the provision and consolidation of maternal health services. MPS strategies are implemented through midwives in villages, midwife partnerships with Traditional Birth Attendants (TBA), and provision of delivery services at all Primary Health Centers (PHCs) [8]. Over the past three decades, Indonesia has made progress in improving maternal health. The proportion of deliveries at healthcare facilities increased from $63 \%(2007-12)$ to $70.4 \%(2010-13)$ [3, 9].
Riau province is located in the central part of Sumatra, Indonesia, with a population of about 6 million [Fig. 1]. Riau consists of ten regencies and two autonomous cities. The proportion of deliveries at healthcare facilities in Riau province (63\%) is lower than the national average [9]. Kuantan Singingi regency is located in Riau province, which is also experiencing improvement in the maternal health program. Skilled birth attendance and delivery at healthcare facilities in this district in 2016 were 85 and $62 \%$, respectively [10]. However, the proportion of deliveries at health facilities was lower than the Ministry of Health strategic plan target of $81 \%[10,11]$.

Factors influencing the utilization of health services can be divided into predisposing, enabling, and need factors [12]. Predisposing factors are maternal age, occupation, attitudes toward healthcare services, knowledge of danger signs of pregnancy, education, and parity [13-15]. Enabling factors are health insurance, socioeconomic status, access to health care, and frequency of antenatal visits [1315]. Need factors are perceptions about risks of pregnancy and childbirth, the presence of danger signs of pregnancy and childbirth, and comorbidities in pregnancy [14]. Previous studies have shown an association of above-said factors with the place of delivery $[6,16,17]$. Determining the factors associated with delivery at healthcare facilities would help in fine-tuning of ongoing maternal health interventions in the local setting.

\section{Objective}

To determine the factors associated with healthcare facility utilization for childbirth in Kuantan Singingi regency, Riau province, Indonesia 2017.

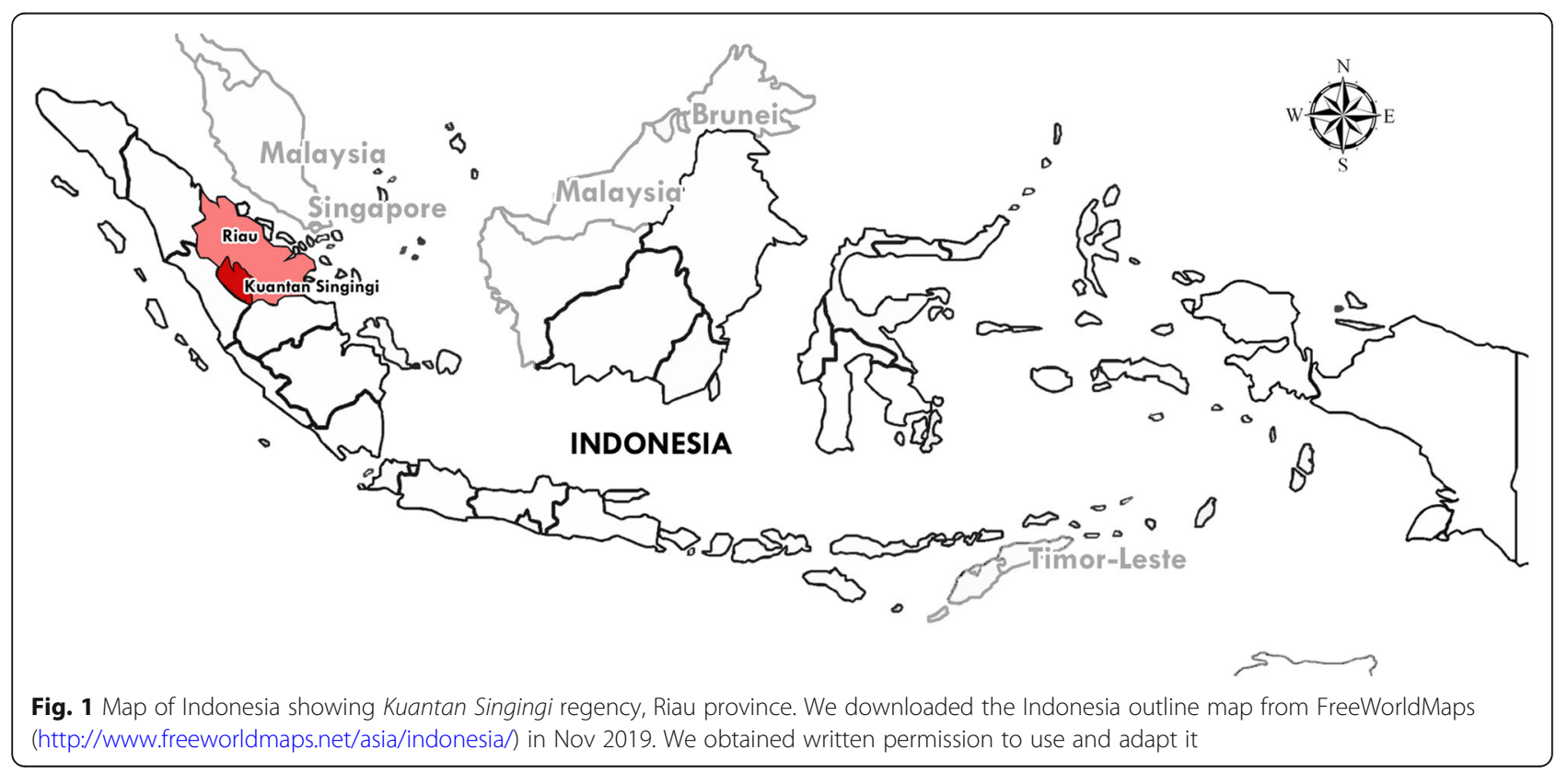




\section{Methods}

\section{Study design and setting}

We conducted a community-based cross-sectional study in 15 sub-districts of Kuantan Singingi regency, Riau province, Indonesia from May-June 2017 [Fig. 1]. Kuantan Singingi regency is located in Sumatra island of Indonesia, with a total population of 2.92 million. It consists of 15 sub-districts. The public health infrastructure consists of 25 PHCs (six with Basic Emergency Obstetric and Neonatal Service, known as PONED), one hospital with Comprehensive Emergency Obstetric and Neonatal Service is known as PONEK, three maternity units, one Mother and Child Hospital and 52 private clinics. PONED PHC to population ratio was 0.95 per 100,000 (standard 1:100,000 population), and midwives to population ratio was 112 per 100,000 (standard 100 per 100 , 000 population).

\section{Sample size}

We estimated the sample size by using the formula for two independent proportions. Based on the reported $50 \%$ of the women who delivered at healthcare facilities had high education, an expected response rate of $90 \%$, and a design effect of 1.1, the study required a total sample size of 314 to achieve a power of $80 \%$ for detecting a difference in proportions of $17 \%$ at a two-sided p-value of $0.05[14,18,19]$.

\section{Inclusion criteria}

We included all the women aged 15-54 years residing in Kuantan Singingi regency and had delivered (irrespective of the place of delivery) in the last 3 months (FebruaryApril 2017).

\section{Sampling}

All the mothers who delivered in the last 3 months in 15 sub-districts formed the sampling frame. We obtained a sub-district wise list of mothers who delivered within 3months (between February and April 2017) from village midwives. The list included all the women irrespective of whether she availed any health service and place of delivery. The samples were drawn from each sub-district based on the proportion probability to size [20]. We selected the first woman by simple random sampling. Subsequently, we included all the consecutive enlisted mothers until the required number was achieved for the sub-district.

\section{Data collection}

We conducted this study in collaboration with the heads of PHCs and facilitated by the District health office Kuantan Singingi. A semi-structured interview guide was used to collect relevant data. To validate the primary data, we used data from the Mother, and Children
Health book or maternal cohort register with village midwife. We trained the data enumerators and supervisors, with a minimum education of bachelor of health, for data collection. Twenty-four data enumerators and six supervisors were trained for 2 days in Pekanbaru City, Riau province, Indonesia. Training included the following: introducing themselves to participants, explaining the purpose of the study, obtaining the written informed consent, interview technique, filling the responses in the questionnaire, interview practice, and supervision.

\section{Operational definitions}

Healthcare facility for childbirth was defined as delivery at a government hospital, private hospital, $\mathrm{PHC}$, doctor's practice, midwife practice, or village maternity post [21]. Delivery at village health post or home with a midwife and/or TBA was considered as non-healthcare facility delivery. In Indonesia, a midwife is a woman who has graduated from a midwifery college, registered, and has a license to practice midwifery. TBA is a person who assists a woman during childbirth and acquired skills by conducting deliveries herself or through apprenticeship to other TBA.

Age of the mother was categorized as low risk (20-35 years) and high risk ( $<20$ years or $>35$ years) for childbirth [22]. The highest level of formal education completed by the mother was categorized as basic (no schooling, elementary school, or junior high school) and senior high school/above [23].

Mothers' occupation was classified as employed (civil servants, military, police, private, self-employed, farmers, and others) and unemployed [24].

We prepared a questionnaire to assess the mothers' attitudes towards healthcare services. We tested the questionnaire for validity and reliability on 30 participants in Kampar regency, Indonesia, whose socio-demographic and cultural profile was similar to the study district. Of the 22 questions, responses to four questions were invalid, and the overall reliability of the questionnaire was high (Cronbach's alpha: 0.974). Attitude scores were estimated for the degree of tendency to approach, like, expectation or tendency to stay away from, avoid, hate, and dislike antenatal care and delivery at healthcare facilities [25]. Attitude was categorized as positive (score $\geq$ mean/median) and negative (score $<$ mean $/$ median). Knowledge of pregnancy danger signs (vaginal bleeding, high fever, convulsions, baby in the wrong position, swelling of the feet/hands/face, fainting, difficulty in breathing, and excessive tiredness) was assessed by scoring [9]. It was categorized as good (score $\geq$ mean $/$ median) and poor (score $<$ mean/median).

Ownership of health insurance was defined as the availability of health protection for mothers to benefit 
health care and protection in meeting basic health needs provided to those who have paid contributions or fees paid by the government [26]. As described in RISKESDAS, we used eight binomial variables for ownership of valuable goods to construct economic status indices using principal component analysis, tetrachoric and polychoric correlation [9]. Economic status was categorized as high (3rd-5th quintile of the study sample) and low (1st-2nd quintile of the study sample).

Using RISKESDAS questionnaire, we assessed access to health services according to the presence of nearby healthcare facilities, travel time, mode of transport used, transport cost, and ease of transportation [9]. It was categorized as easy (score $\geq$ mean/median) and difficult (score $<$ mean/median). Antenatal care was considered as complete if the mother had at least four antenatal visits (first within 3 months, second between four and 6 months, twice between seven and 9 months) during pregnancy [27]. Perceived risk of pregnancy and childbirth was assessed according to the respondent's immediate response to the harmful outcomes of pregnancy and childbirth [28]. It was categorized as high (score $\geq$ mean/median) and low (score $<$ mean/median).

Presence of danger signs of pregnancy (vaginal bleeding, high fever, convulsions, baby in wrong position, swelling of the feet/hands/face, fainting, difficulty in breathing, excessive tiredness) and childbirth (bleeding, convulsions, and or bleeding diagnosis, severe preeclampsia, premature rupture of membranes) were assessed and scored. Mother was categorized as high (score $\geq$ cut of point Receiver Operating Characteristic, ROC) and low risk (score < cut of point ROC) [27, 29, 30]. Presence of comorbidity in pregnancy, such as malaria, pulmonary tuberculosis, asthma, diabetes mellitus, severe anemia, urinary tract infections, have experienced events that resulted in injury so that daily activities are disrupted were noted [31].

\section{Statistical analysis}

We used STATA ${ }^{\circ}$ version 12 for data analysis. Descriptive statistics were used for categorical and continuous variables [32, 33]. Univariate analysis was done by Chisquare test and prevalence ratio (PR) with $95 \%$ confidence interval at a significance limit $(\alpha)$ of $5 \%$ [33, 34]. Multivariate analysis was done using a modified Cox Proportional Hazard Regression (cox regression). We used PR in modified cox regression as the prevalence of the outcome was $>10 \%$. In modified cox regression, the timing of the selection of the delivery place was considered as constant or at the same time. Survival time in cox regression was determined by the same number (i.e., 1) with an assumption that the choice of delivery place occurs on the day of the interview. The required PR score for this study was adjusted for Hazard Ratio (HR) resulting from the Cox test since HR was the outcome in the exposed and unexposed groups [35].

All the study variables with $p \leq 0.25$ on univariate analysis were considered into a multivariable model. The possible effects of modification/interaction of variables into the model were examined. The modified/interaction effect assessment should have a meaningful p-value with the important interaction variable to be included in the model. We assessed the interaction by entering one by one variable that was suspected of having interaction in the initial model. An initial Hierarchically Well Formulated Model (HWF Model) or most complete model was created. In the HWF model (full model), variable having $p$ value $>0.05$ was eliminated, starting from the largest $\mathrm{p}$ value. The result of this modeling is a reduced model. Based on the Log LR (Likelihood Ratio) test, the variable was considered not significant and not included in the model if the LR $>3.8$. The final model was described based on the final test results and interaction of dependent and independent variables.

\section{Ethical approval}

Ethical Commissions of Research and Community Service, Faculty of Public Health, University of Indonesia, Indonesia approved the study (275/UN2.F10/PPM.00.02/ 2017). Trained data enumerators obtained the written informed consent from the study participants for voluntary participation. Informed consent was taken from the parent or legal guardian if the woman aged $<18$ years. Investigators followed the ethical principles of Helsinki Declaration-2013 and International Ethical Guidelines for Epidemiological Studies [36, 37].

\section{Results}

We approached 320 eligible mothers, and all of them participated in the study. Their mean age $( \pm \mathrm{SD})$ was 28 $( \pm 5.75)$ years. Table 1 shows the mothers' key sociodemographic and obstetric characteristics. Of the 320 mothers, 174 (54.38, 95\% CI: 48.8-59.9\%) delivered at healthcare facilities. Private hospitals $(77,24.1 \%)$ and midwife practice $(57,17.8 \%)$ were the preferred places of delivery. Nearly two-thirds (63\% and overall $28.8 \%$ ) of the non-healthcare deliveries were conducted at home by midwife [Table 2].

Table 3 shows the association of various study variables with childbirth at healthcare facilities. The following factors had a significant association $(p<0.05)$ with childbirth at healthcare facilities: maternal education, maternal employment, attitudes towards healthcare services, knowledge of danger signs of pregnancy, complete antenatal care visits, access to health care, and perceived risk of pregnancy, and childbirth.

In multivariate analysis, an initial model was prepared with all the variables with $p<0.25$ on bivariate analysis, 
Table 1 Key socio-demographic and obstetric characteristics of mothers in Kuantan Singingi regency, Riau province, Indonesia $2017(N=320)$

Variable
Mother's age
Low risk ( $20-35$ years)
High risk ( $<20$ or $>35$ years)
Education

Education

Senior high school/above

Basic

Employment status

Employed

Unemployed

Parity

$1-2$

$\geq 3$

Economic status

High

Low

Place of delivery

Health facility

Non-health facility

Attitudes towards health services

Positive

Negative

Ownership of health insurance

Insured

Not insured

Knowledge of danger signs of pregnancy

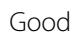

Poor

Antenatal care visits

Complete ( $\geq 4$ visits)

Incomplete ( $<4$ visits)

Access to health services

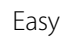

Difficult

Perceived risk of pregnancy and childbirth Good

Presence of danger sign of pregnancy

High risk

Low risk

Presence of danger sign of childbirth

High risk

Low risk
$\%$

79.1

20.9

60.6

39.4

21.3

78.8

71.6

28.4

48.4

51.6

54.4

45.6

58.1

41.9

48.8

51.3

59.7

40.3

73.1

26.9

90.9

9.1

54.7

54.7
45.3

45.3

2.2

97.8

11.3

88.8
Table 1 Key socio-demographic and obstetric characteristics of mothers in Kuantan Singingi regency, Riau province, Indonesia $2017(N=320)$ (Continued)

\begin{tabular}{lll}
\hline Variable & $\mathrm{n}$ & $\%$ \\
\hline $\begin{array}{ll}\text { Comorbidities in pregnancy } \\
\text { Yes }\end{array}$ & 16 & 5 \\
No & 304 & 95 \\
\hline
\end{tabular}

and interaction assessment was done by forward entry. The following nine variables were included in the initial model: maternal education, maternal employment, attitudes towards healthcare services, knowledge of danger signs of pregnancy, health insurance, complete antenatal care visits, access to health care, and perceived risk of pregnancy and childbirth.

Table 4 shows the final model by backward elimination for determinants of childbirth at healthcare facilities. Good knowledge of danger signs of pregnancy (PR: 1.59, 95\%CI:1.15-2.2) and access to healthcare services (PR:0.39, 95\%CI:0.18-0.84) were the determinants of childbirth at healthcare facilities in Kuantan Singingi regency, Indonesia.

In this research, there was an interaction between attitude and access to healthcare services, so its PR value cannot be interpreted directly, but through some calculation phases [Table 5]. Based on the calculation of interaction PR, mothers who had easy access to healthcare were more likely to choose healthcare facilities for childbirth irrespective of their attitudes (positive/negative) towards healthcare facilities when compared to mothers who had a negative attitude and difficult access (reference group). When compared to the reference group, mothers with difficult access to the healthcare

Table 2 Distribution of recently delivered mothers according to place of childbirth in Kuantan Singingi regency, Riau province, Indonesia 2017 ( $N=320)$

\begin{tabular}{lll}
\hline Place of childirth & $\mathrm{n}$ & $\%$ \\
\hline Goverment hospital & 7 & 2.2 \\
Private Hospital & 77 & 24.1 \\
Primary healthcare centre (Puskesmas) & 7 & 2.2 \\
Doctor's Practice & 21 & 6.6 \\
Midwife Practice & 57 & 17.8 \\
Village Maternity Post & 5 & 1.6 \\
Village Health Post & 9 & 2.8 \\
Home by Midwife & 92 & 28.8 \\
Home by Doctor & 4 & 1.3 \\
Home by TBA (Dukun beranak) & 13 & 4.1 \\
House by Midwife and TBA & 27 & 8.4 \\
Home by Doctor partner, Midwife and TBA & 1 & 0.3 \\
\hline
\end{tabular}


Table 3 Association of various study variables with child birth at healthcare facilities in Kuantan Singingi regency, Riau province, Indonesia $2017(N=320)$

\begin{tabular}{|c|c|c|c|c|c|c|}
\hline \multirow[t]{3}{*}{ Variable } & \multicolumn{4}{|c|}{ Place of delivery } & \multirow[t]{3}{*}{ PR } & \multirow{3}{*}{$\begin{array}{l}\text { PR }(95 \% \\
\text { Cl) }\end{array}$} \\
\hline & \multicolumn{2}{|c|}{ Healthcare facility $(\boldsymbol{n}=174)$} & \multicolumn{2}{|c|}{ Non-healthcare facility $(\boldsymbol{n}=146)$} & & \\
\hline & $n$ & $\%$ & $n$ & $\%$ & & \\
\hline \multicolumn{7}{|l|}{ Predisposing factors } \\
\hline \multicolumn{7}{|l|}{ Mother's Age } \\
\hline Low risk (20-35 years) & 135 & 53 & 118 & 47 & 0.91 & $0.72-1.15$ \\
\hline High risk ( $<20$ or $>35$ years) & 39 & 58 & 28 & 42 & 1 & \\
\hline \multicolumn{7}{|l|}{ Mother's education } \\
\hline Senior high school/above & 116 & 59.8 & 78 & 40.2 & $1.29^{*}$ & $1.04-1.62$ \\
\hline Basic & 58 & 46 & 68 & 54 & 1 & \\
\hline \multicolumn{7}{|l|}{ Employment status } \\
\hline Employed & 45 & 66 & 23 & 34 & $1.29^{*}$ & $1.04-1.59$ \\
\hline Unemployed & 129 & 51 & 123 & 49 & 1 & \\
\hline \multicolumn{7}{|l|}{ Parity } \\
\hline $1-2$ & 126 & 55 & 103 & 45 & 1.04 & $0.83-1.31$ \\
\hline$\geq 3$ & 48 & 53 & 43 & 47 & 1 & \\
\hline \multicolumn{7}{|c|}{ Attitudes towards health services } \\
\hline Positive & 124 & 66.7 & 62 & 33.3 & $1.78^{*}$ & $1.4-2.27$ \\
\hline Negative & 50 & 37.3 & 84 & 62.7 & 1 & \\
\hline \multicolumn{7}{|c|}{ Knowledge of danger signs of pregnancy } \\
\hline Good & 124 & 64.9 & 67 & 35.1 & $1.55^{*}$ & $1.27-1.89$ \\
\hline Poor & 50 & 38.8 & 79 & 61.2 & 1 & \\
\hline \multicolumn{7}{|l|}{ Enabling factors } \\
\hline \multicolumn{7}{|l|}{ Economic status } \\
\hline High & 80 & 46 & 75 & 51 & 0.89 & $0.71-1.12$ \\
\hline Low & 94 & 54 & 71 & 49 & 1 & \\
\hline \multicolumn{7}{|l|}{ Ownership of health insurance } \\
\hline Insured & 90 & 58 & 66 & 42 & 1.12 & $0.92-1.37$ \\
\hline Not insured & 84 & 51 & 80 & 49 & 1 & \\
\hline \multicolumn{7}{|l|}{ Antenatal care visits } \\
\hline Complete ( $\geq 4$ visits) & 141 & 60 & 93 & 40 & $1.57^{*}$ & $1.17-2.09$ \\
\hline Incomplete (< 4 visits) & 33 & 38 & 53 & 62 & 1 & \\
\hline \multicolumn{7}{|l|}{ Access to health services } \\
\hline Easy & 152 & 52.2 & 139 & 47.8 & $0.68^{*}$ & $0.54-0.86$ \\
\hline Difficult & 22 & 75.9 & 7 & 24.1 & 1 & \\
\hline
\end{tabular}

\section{Need factors}

Perceived risk of pregnancy and childbirth

$\begin{array}{ll}\text { Good } & 108 \\ \text { Bad } & 66\end{array}$

Presence of danger signs of pregnancy

$\begin{array}{ll}\text { High risk } & 4 \\ \text { Low risk } & 170\end{array}$

Presence of danger signs of childbirth 
Table 3 Association of various study variables with child birth at healthcare facilities in Kuantan Singingi regency, Riau province, Indonesia 2017 ( $N=320)$ (Continued)

\begin{tabular}{|c|c|c|c|c|c|c|}
\hline \multirow{3}{*}{$\begin{array}{l}\text { Variable } \\
\text { Low risk }\end{array}$} & \multicolumn{4}{|c|}{ Place of delivery } & \multirow{3}{*}{$\begin{array}{l}\text { PR } \\
1\end{array}$} & \multirow{3}{*}{$\begin{array}{l}\text { PR (95\% } \\
\text { Cl) }\end{array}$} \\
\hline & \multicolumn{2}{|c|}{ Healthcare facility $(\boldsymbol{n}=174)$} & \multicolumn{2}{|c|}{ Non-healthcare facility $(\boldsymbol{n}=146)$} & & \\
\hline & 154 & 54.2 & 130 & 45.8 & & \\
\hline \multicolumn{7}{|c|}{ Comorbidity in pregnancy } \\
\hline Present & 13 & 81 & 3 & 19 & $1.53^{*}$ & $1.18-1.98$ \\
\hline Absent & 161 & 53 & 135 & 47 & 1 & \\
\hline
\end{tabular}

${ }^{*} p<0.05$

facility and positive attitude towards healthcare facilities were more likely to deliver at the non-healthcare facility.

\section{Discussion}

In Kuantan Singingi regency, the utilization of healthcare facilities for childbirth was much lower than the Ministry of Health's strategic plan target of $81 \%[10,11]$. A qualitative research in Tangerang district, Banten, Indonesia, reported that mothers were more comfortable to deliver at home in the presence of family members, who provide support during delivery. Mothers choose TBA as a birth attendant due to customary use of TBA services [38]. Similar qualitative studies in Kuantan Singingi regency could help to understand the reasons for preference for home deliveries.

Among the deliveries at healthcare facilities, every fourth and sixth woman delivered at private hospitals and midwife practice, respectively. Previous studies in Indonesia reported that the type of healthcare facility was chosen based on the proximity, infrastructure, skilled personnel, previous experience of parents, and in-laws [28, 39]. Similar factors may have played a role in deciding the type of health facility for delivery in this study.

In Indonesia, TBA (known as 'Dukun beranak') is also very popular for conducting deliveries. However, these do not have any medical expertise, and their role is restricted (by the Ministry of Health) to support the mothers. A midwife or medical personnel should conduct the delivery. Ministry of Health developed a partnership program between TBAs and midwives so that TBAs act as a link between the healthcare system and community [40]. TBA is expected to mentor pregnant women for full antenatal care, delivery at healthcare facility, escort her to midwife for delivery and care of the newborn. In the study setting, there is a need for reorientation and capacity building of midwives and TBAs to enhance childbirth at healthcare facilities.

Various studies across the globe have studied the association between childbirth at healthcare facilities and maternal factors such as age, education status, employment status, and parity [7, 13, 41-45]. In this study, none of these showed significant association with childbirth at healthcare facilities.

Previous studies from Indonesia and Ghana have reported the positive impact of health insurance on the utilization of healthcare facilities for delivery $[13,46]$. In 2014, Indonesia launched a national health insurance scheme (Jaminan Kesehatan Nasional, JKN). It aims to provide universal health coverage to the entire Indonesian population by 2019. In this study, almost half of the mothers had health insurance. However, there was no association between health insurance and the utilization of healthcare facilities for childbirth. Whether it was a serendipitous finding or issues such as out-of-pocket expenditure, poor implementation, or acceptability of JKN, etc. needs further exploration.

Lower utilization of existing healthcare facilities by economically poor mothers has been consistent in previous studies from Indonesia, Thailand, other Asian countries, Africa, and Latin America [13, 4749]. However, this was not significant in this study, although $51.6 \%$ of the mothers were from a low economic background. This could be attributed to improved use of healthcare services by the poor in the regency or methodological differences in assessing the economic status in different countries.

Table 4 Final cox regression model of determinants of childbirth at health facilities in Kuantan Singingi regency, Riau province, Indonesia $2017(N=320)$

\begin{tabular}{llllll}
\hline Variable & Coef $\beta$ & SE & PR & $95 \% \mathrm{Cl}$ & $\boldsymbol{p}$-value \\
\hline Knowledge of danger signs of pregnancy & 0.469 & 0.268 & 1.59 & $1.15-2.22$ & $0.005^{*}$ \\
Access to health services & -0.922 & 0.153 & 0.39 & $0.18-0.84$ & $0.017^{*}$ \\
Attitudes towards health services & -0.231 & 0.351 & 0.79 & $0.33-1.89$ & 0.601 \\
Attitude * access to health services & 0.880 & 1.155 & 2.41 & $0.94-6.16$ & 0.066 \\
\hline
\end{tabular}


Table 5 Results of prevalence ratio interaction with health service attitudes and access to health services among mothers in Kuantan Singingi regency, Riau province, Indonesia 2017 ( $N=$ 320)

\begin{tabular}{lll}
\hline Interaction variable & PR interaction & $95 \% \mathrm{Cl}$ \\
\hline Positive attitude, easy access & 1.91 & $1.34-2.73$ \\
Positive attitude, difficult access & 0.793 & $0.33-1.89$ \\
Negative attitude, easy access & 2.41 & $0.94-6.17$ \\
Negative attitude, difficult access & 1 (reference) & - \\
\hline
\end{tabular}

Attitude ( $1=$ positive attitude, $0=$ negative attitude), Access ( $1=$ easy access, $0=$ difficult access)

Studies from Indonesia [15] and Ethiopia [46] have shown that mothers with positive attitudes towards available healthcare services are more likely to deliver at a healthcare facility. However, we did not find a similar significant association in this study.

In this study, mothers with easy access to healthcare services were less likely to use healthcare facilities for childbirth when compared to their counterparts. The observed interaction between access to healthcare and attitudes is a possible explanation. Irrespective of their attitudes towards healthcare facilities, mothers with easy access to healthcare facility were more likely to choose healthcare facility for childbirth. However, other factors such as cost of healthcare service (especially in urban areas), cultural factors, and service time influencing childbirth at healthcare facilities were not studied in this study [13, 38].

According to Fosu GB [50], the utilization of healthcare services depends on the perceived risk of present condition and benefits of the treatment. Similar findings were also seen in this and another study from Indonesia [15]. In this study, knowledge of danger signs of pregnancy was an independent correlate of childbirth at healthcare facilities. Perceived risk plays a role in shaping mothers' decisions and actions and influenced by other factors such as antenatal care visits, age, occupation, etc. [7]. Women with sufficient knowledge of danger signs are capable of early recognition of potentially life-threatening complications and avert unnecessary delay in seeking healthcare [51]. Hence, education about the danger signs during antenatal care visits should be emphasized. However, the presence of danger signs of pregnancy and childbirth were not associated with delivery at healthcare facilities, although others reported contrary findings $[49,50,52]$. Very few mothers experienced danger signs of pregnancy (2.2\%) and childbirth (11.3\%), differences in the study setting could be a possible explanation. Mothers with comorbidities during pregnancy are at high risk of morbidity and mortality, and they directly affect the utilization of healthcare services $[12,53]$. However, in this study, we did not observe a significant association between comrbidity and childbirth at healthcare facilities.
In a developing country like Indonesia, especially in the Muslim culture, the decision-making system is patriarchal. Family members like husband, parents, and, inlaws play a crucial role in deciding the place of childbirth [38, 54, 55]. However, the present study focused only on the woman as a participant.

\section{Strengths and limitations}

The study participants were selected from 15 subdistricts and fairly represented recently delivered mothers in the regency. To minimize the recall bias, only mothers delivered in the last 3 months were included, and, wherever possible, information obtained from the interviews was verified with Mother, and Children Health book records. To minimize the possibility of misclassification bias, we used RISKESDAS standard questionnaire (2010 and 2013) to assess the economic status and access to health services. RISKESDAS economic status questionnaire is relatively easy and widely used in developing countries. The limitation is determining the weight for each item. The access to health services questionnaire uses weighted difficulty levels. However, the respondent's answer might be subjective, such as determining travel time. Associations observed in this study may not imply causality owing to the cross-sectional study design. This study did not consider husband, parents, and, in-laws-related factors which may influence in deciding the place of childbirth.

\section{Conclusions}

In Kuantan Singingi regency, childbirth at healthcare facilities was low. We recommend strengthening of existing maternal and child health program with a particular emphasis on imparting complete and quality antenatal care, health education on danger signs of pregnancy and childbirth, and promoting positive attitudes towards healthcare facilities. These interventions are known to change the behavior and reduce the maternal and neonatal mortalities in low-resources settings [56, 57]. Further studies are needed to explore the role of health insurance and accessibility to healthcare in utilization of available facilities.

\section{Abbreviations \\ Cl: Confidence Interval; HR: Hazard Ratio; HWF Model: Hierarchically Well Formulated Model; JKN: Jaminan Kesehatan Nasional (National Health Insurance); LR: Likelihood Ratio; MMR: Maternal Mortality Ratio; MPS: Making Pregnancy Safer; PHC: Primary Health Centers; PONED: Basic Emergency Obstetric and Neonatal Service; PONEK: Comprehensive Emergency Obstetric and Neonatal Service; PR: Prevalence Ratio; RISKESDAS: Indonesia Basic Health Research; ROC: Receiver Operating Characteristic; SDGs: Sustainable Development Goals; TBA: Traditional Birth Attendants}

\section{Acknowledgements}

Authors acknowledge Mrs. Agustin Kusumayati, Mr. Mondastri Korib, Mr. Rusli, Mr. Anwar Hassan, Mr. Yovsyah, Mrs. Milwiyandia, Mr. Jajang Mulyana, and Mr. Irwan Muryanto for their inputs to this study. Authors thank heads of the Riau Provincial Health Office, Kuantan Singingi District Health Office, and 
Community Health Centers, enumerators, and supervisors for their help in field data collection. Authors also thank Director, FETP Indonesia and SAFETYNET (South Asia Field Epidemiology and Technology Network, Inc.) for their guidance.

\section{Authors' contributions}

RS and TW conceived and designed the study, led the data collection, statistical analysis and drafted the manuscript. SS significantly contributed to the interpretation of the results, drafting and critically revising the manuscript. All authors have read and approved the manuscript.

\section{Funding}

This publication was supported by a grant from the Centers for Disease Control and Prevention (CDC) through TEPHINET, a program of the Task Force for Global Health, Inc., and a scholarship from Government of Riau province, Indonesia. Its contents are solely the responsibility of the authors and do not necessarily represent the views of The Task Force for Global Health, Inc. TEPHINET, CDC, or the Government of Riau province, Indonesia. The funders had no role in study design, data collection, and analysis, decision to publish, or preparation of the manuscript.

\section{Availability of data and materials}

The datasets used and/or analyzed during the current study are available from RS (rigoners@yahoo.co.id) on reasonable request.

\section{Ethics approval and consent to participate}

Ethical Commissions of Research and Community Service, Faculty of Public Health, University of Indonesia, Indonesia approved the study (275/UN2.F10/ PPM.00.02/2017). Written informed consent was obtained from the study participants for voluntary participation. Informed consent was taken from the parent or legal guardian if the woman aged $<18$ years. Ethical principles of Helsinki Declaration-2013 and International Ethical Guidelines for Epidemiological Studies were followed throughout the study.

\section{Consent for publication}

Not applicable.

\section{Competing interests}

The authors declare that they have no competing interests.

\section{Author details}

'Department of Epidemiology, Faculty of Public Health, Universitas Indonesia, Prof. Dr. Bahder Djohan Street, Depok 16424, Indonesia. ${ }^{2}$ Department of Disease Prevention and Control, Riau Provincial Health Office, Cut Nyak Dien III Street, Pekanbaru 28126, Indonesia. ${ }^{3}$ Non-Communicable Diseases Regional Technical Advisor, Southeast Asia Regional Office (SEARO), TEPHINET, A Program of the Task Force for Global Health, Inc., Decatur, GA 30030, USA. ${ }^{4}$ Department of Medical Statistics, London School of Hygiene \& Tropical Medicine, London WC1E 7HT, UK.

Received: 24 July 2019 Accepted: 3 June 2020

Published online: 15 June 2020

\section{References}

1. Alkema L, Chou D, Hogan D, Zhang S, Moller A, et al. Global, regional, and national levels and trends in maternal mortality between 1990 and 2015, with scenario-based projections to 2030: A systematic analysis by the UN maternal mortality estimation inter-agency group. Lancet. 2016;387(10017): 462-74 Jan-Feb [cited 2017 July 10]. Available from: http://www. sciencedirect.com/science/article/pii/S0140673615008387.

2. World Health Organization. Trends in maternal mortality: 1990 to 2015. Estimates by WHO, UNICEF, UNFPAM, World Bank Group and the United Nations Population Division: World Health Organization; 2015. Available from http://www.who.int/reproductivehealth/publications/monitoring/ maternal-mortality-2015/en/.

3. Nuraini S, Wahyuni T, Windiarto E, Karyono OS. Profil Penduduk Indonesia Hasil SUPAS 2015. Jakarta: Badan Pusat Statistik; 2016.

4. Chowdhury ME, Ahmed A, Kalim N, Koblinsky M. Causes of materna mortality decline in matlab, Bangladesh. J Health Popul Nutr. 2009;27(2): 108-23 [Cited 2017 April 14]. Available from: https://www.ncbi.nlm.nih.gov/ pmc/articles/PMC2761779/.
5. Prameswari MF. Kematian perinatal di Indonesia dan faktor yang berhubungan, tahun 1997-2003. Jurnal Kesehatan Masyarakat Nasional. 2007;1 (14):154-60 February [cited 2017 Juli 10]. Available from: http:// journal.fkm.ui.ac.id/kesmas/article/view/298.

6. Thaddeus S, Maine D. Too far to walk: maternal mortality in context. Soc Sci Med. 1994;38(8):1091-110.

7. Stekelenburg J, Kyanamina S, Mukelabai M, Wolffers I, van Roosmalen J. Waiting too long: Low use of maternal health services in Kalbo, Zambia. A Eur J TMIH. 2004;9(13):390-8. March [cited 2017 April 14]. Available from:: https://doi.org/10.1111/j.1365-3156.2004.01202.x/full.

8. Departemen Kesehatan RI. Rencana strategis nasional Making Pregnancy Safer (MPS) di Indonesia 2001-2010. Departemen Kesehatan RI: Jakarta; 2005.

9. Badan Penelitian dan Pengembangan Kesehatan. Riset Kesehatan Dasar, Riskesdas. Jakarta: Kementerian Kesehatan Rl; 2013. p. 2013.

10. Dinas Kesehatan Kabupaten Kuantan Singingi. Profil Kesehatan Kabupaten Kuantan Singingi. Teluk Kuantan: Dinas Kesehatan Kabupaten Kuantan Singingi; 2016.

11. Dinas Kesehatan Kabupaten Kuantan Singingi. Laporan PWS KIA Kabupaten Kuantan Singingi tahun 2016. Teluk Kuantan: Dinas Kesehatan Kabupaten Kuantan Singingi; 2017.

12. Andersen $\mathrm{R}$, Newman J. Societal and individual determinants of medical care utilization in The United State. Milbank Q. 2005;83(4):1-28. https://doi. org/10.1111/j.1468-0009.2005 November [cited 2017 June 14]. Available from 00428.x/ full.

13. Arief M S. Determinan pemilihan persalinan di fasilitas kesehatan (analisis data riset kesehatan dasar tahun 2010). Jurnal Kesehatan Reproduksi. 2014; 5(3) [cited 2017 June 14]Available from: http://ejournall.itbang.kemkes.go.id/ index.php/kespro/article/ view/3892/3737.

14. Maimunah. Determinan Pemanfaatan Layanan Persalinan (Analisis Data SDKI 2007). [Tesis]. Depok: Pasca Sarjana FKM Ul; 2010

15. Khaeruddin. Determinan pemanfaatan pertolongan persalinan oleh tenaga kesehatan di Puskesmas Cijeruk tahun. Depok: [Tesis], Pasca Sarjana FKM Ul; 2012.

16. Stephenson R, Baschieri A, Clements S, Hennink M, Madise N. Contextual influences on the use of health facilities for Childbirth in Africa. AJPH. 2006: 96(1). https://doi.org/10.2105/AJPH.2004 January [cited 2017 April 12]. Available from: . 57422.

17. Bonfrer I, Breebaart L, Van de Poel E. The effects of Ghana's national health insurance scheme on maternal and infant health care utilization. PLoS One. 2016;11(11) November [cited 2017 April 12]. Available from: http://journals. plos.org/plosone/article?id=10.1371/journal.pone.0165623.

18. Sabri L, Hastono SP. Statistik Kesehatan. Rajawali Pers: Jakarta; 2014.

19. Lemeshow S. Besar sampel dalam penelitian kesehatan. Yogyakarta: Gajah Mada University Press; 1997.

20. Sastroasmoro S, Ismael S. Dasar-dasar penelitian: metodologi penelitian klinis. 4th ed. Jakarta: Sagung Seto; 2011.

21. Mubarak WI. IImu kesehatan masyarakat: konsep dan aplikasi dalam kebidanan. Jakarta: Salemba Medika; 2014

22. Indonesia KKR. Pedoman Pemantauan Wilayah Setempat Kesehatan Ibu dan Anak (PWS KIA). Jakarta: Direktorat Jenderal Bina Kesehatan Masyarakat; 2010

23. Undang-Undang Nomor 20 Tahun 2003- Sistem Pendidikan Nasional. Produk Hukum | JDIH Kementerian Sekretariat Negara. 2003. [cited 8 January 2020]. Available from: https://jdih.setneg.go.id/viewpdfperaturan/ P01199/UU0202003

24. Nurasih RD. Faktor-faktor yang berhubungan dengan persalinan pada non fasilitas kesehatan di Indonesia tahun 2013. Depok: Pasca Sarjana FKM UI; 2015.

25. Purwanto H. Pengantar perilaku manusia untuk keperawatan. Jakarta: EGC; 1998.

26. Kementerian Kesehatan RI. Peraturan Menteri Kesehatan Republik Indonesia Nomor 71 tahun 2013 tentang pelayanan kesehatan pada jaminan kesehatan nasional. Jakarta: Kementerian Kesehatan Rl; 2013.

27. Indonesia KKR. Buku Kesehatan Ibu dan Anak. Jakarta: Kementerian Kesehatan dan JICA; 2015.

28. Suryawati C. Faktor Sosial Budaya dalam Praktik Perawatan Kehamilan, Persalinan, dan Pasca Persalinan (Studi di Kecamatan Bangsri Kabupaten Jepara). Jurnal Promosi Kesehatan Indonesia. 2007;2(1) January [cited 2017 April 12];Available from: http://www.ejournal.undip.ac.id/index.php/jpki/ article/view/2800. 
29. Rochjati P. Skrining Antenatal Pada Ibu Hamil. 2nd ed. Surabaya: Airlangga University Press; 2011.

30. Badan Penelitian dan Pengembangan Kesehatan. Riset Kesehatan Dasar, Riskesdas 2010. Jakarta: Kementerian Kesehatan Rl; 2010.

31. Reeder SJ, Martin LL, Koniak-Griffin D. Keperawatan maternitas: kesehatan wanita, bayi dan keluarga. vol. 2. 18th ed. Jakarta: EGC; 2014

32. Dahlan MS. Statistik untuk kedokteran dan kesehatan. 5th ed. Jakarta: Salemba Medika; 2011.

33. Hastono SP. Analisis data kesehatan. Depok: Fakultas Kesehatan Masyarakat Universitas Indonesia; 2007

34. Gerstman B. Epidemiology kept simple: an introduction to traditional and modern epidemiology. 3rd ed. Oxford: Wiley-Blackwell; 2013.

35. Kleinbaum DG, Klein M. Logistic regression: a self-learning text. 3rd ed. New York: Springer; 2010.

36. World Medical Association. World medical association declaration of Helsinki: Ethical principles for medical research involving human subjects. Bull World Health Organ. 2001;79(4):373-4 [cited 2017 April 10] Available from: https://www.ncbi.n/m.nih.gov/pmc/articles/PMC2566407/.

37. Council for International Organization of Medical Science. International ethical guidelines for epidemiological studies. . 2008 [cited 2017 April 10]. Available from: https://www.ufrgs.br/bioetica/cioms2008.pdf.

38. Eryando T. Alasan pemeriksaan kehamilan dan pemilihan penolong persalinan. Jurnal Administrasi Kebijakan Kesehatan. 2006:47-51 [cited 2017 April 12]. Available from http://journal.unair.ac.id/download-fullpapers-8. Tris\%20Eryando.pdf.

39. Susilowati R. Pola pengambilan keputusan keluarga dan penolong persalinan dalam memutuskan merujuk ibu bersalin ke Rumah Sakit pada kasus kematian ibu bersalin di Kabupaten Semarang tahun 2000. 2001 [cited 2017 April 12]. Available from: http://eprints.undip.ac.id/13653/1/2001 MKES1018.pdf.

40. Direktorat Jenderal Bina Kesehatan Masyarakat. Pedoman kemitraan bidan dan dukun. Jakarta: Departemen Kesehatan Rl; 2008.

41. Burgard S. Race and pregnancy-related care in Brazil and South Africa. Soc Sci Med J. 2004:59(6):1127-46 September [cited 2017 April 12]: Available from: http://www.sciencedirect.com/science/article/pii/S0277953604000085.

42. Raghupathy S. Education and the use of maternal health care in Thailand. Soc Sci Med J. 1996;43(4):459-71 [Cited 2017 April 12]; Available from: http://www.sciencedirect.com/science/article/pii/0277953695004114.

43. Thorsen VA, Sundby J, Malata A. Piecing together the maternal death puzzle through narratives: the three delays model revisited. J PLOS ONE. 2012;7(12): e52090. [cited 2017 April 14]Available from:. https://doi.org/10.1371/journal. pone.0052090

44. Gabrysch S, Campbell OMR. Still too far to walk: literature review of the determinants of delivery service use. BMC Pregnancy Childbirth. 2009;9(34): 1471-2393 August [cited 2017 April 12]. Available from: https:// bmcpregnancychildbirth.biomedcentral.com/ articles/10.1186/1471-2393-934.

45. Jekti RP, Mutiatikum D. Hubungan antara kepatuhan antenatal care dengan pemilihan penolong persalinan. Jurnal Kesehatan Reproduksi. 2011;1(2) April [cited 2017 April 12]. Available from: http://ejournal.litbang.depkes.go.id/ index.php/kespro/article/view/1348.

46. Debelew GT, Afewok MF, Yalew AW. Factors affecting birth preparedness and complication readiness in Jimma Zone, South West Ethiopia: a multilevel analysis. Pan Afr Med J. 2014;19(272) November [cited 2017 April 12]. Available from: https://www.ncbi.nlm.nih.gov/pmc/articles/PMC4391 899/pdf/PAMJ-19-272.pdf.

47. Langi FLFG, Langi G. Barriers to delivery care by skilled attendants in Sulawesi Utara. J Public Health Development. 2009;7(3) Sept-Dec [cited 2017 April 12]; Available from: http://www.aihd.mahidol.ac.th/sites/default/files/ images/new/pdf/journal/sepdec2009/1-13.pdf.

48. Pomeroy A, Koblinsky M, Alva S. Private delivery care in developing countries: trends and determinants. Demographic Health Res. 2010; October [cited 2017 April 12]; No. 76. Available from: http://dhsprogram.com/pubs/ pdf/WP76/WP76.pdf.

49. Chackraborty N, Islam MA, Chowdhury RI, Bari W, Akhter HN. Determinants of the use of maternal health services in rural Bangladesh. Health Promot Int. 2003;18(4):327-37 [cited 2017 April 12]. Available from: https://oup. silverchair-cdn.com/oup/backfile/Content_public/Journal/heapro/18/4/10.1 093/heapro/dag414/2/dag414.pdf.

50. Fosu GB. Childhood morbidity and health services utilization: cross-national comparisons of user-related factors from DHS data. Soc Sci Med. 1994;38(9):
1209-20 May [cited 2017 April 12]Available from: http://www.sciencedirect. com/science/article/pii/0277953694901864.

51. JHPIEGO. Maternal and neonatal health. Monitoring birth preparedness and complication readiness, tools and indicators for maternal and newborn health. Johns Hopkins, Bloomberg school of Public Health, Center for communication programs, Family Care International; 2004. [cited 2019 Nov 08]. Available from: http://www.jhpiego.org/files/BPCRtoolkit.pdf.

52. Mahwati Y. Pemanfaatan pelayanan kesehatan ibu di Jawa Barat. Jurnal Kesehatan Masyarakat Nasional. 2013;7(6):257-64 [Cited 2017 April 12]Available from: http://jurnalkesmas.ui.ac.id//kesmas/article/view/35/36.

53. Sibai BM. Diagnosis, prevention, and management of eclampsia. Obstetric Gynocol. 2005;105(2):402-10 [Cited 2017 April 12]. Available from: http:// journals.Iww.com/greenjournal/Abstract/2005/02000/Diagnosis,_Prevention, and_Management_of_Eclampsia.31.aspx.

54. Imran LOA, Asfian P. Rahmatia. Determinants of Mother's choice of place delivery in Community of Bajo, Muna District: A qualitative study. Public Health Indonesia. 2016:2(3):155-9.

55. Efendi F, Ni'mah AR, Hadisuyatmana S, Kuswanto $H$, Lindayani L, Berliana SM. Determinants of facility-based childbirth in Indonesia. ScientificWorldJournal. 2019:2019:9694602.

56. Koblinsky M, Favin M, Kureshy N, Elder L. Behavioral Dimensions of Health and Survival. Mother Care Matters. 2000:9(3):1-19.

57. Soubeiga D, Gauvin L, Hatem MA, Johri M. Birth Preparedness and Complication Readiness (BPCR) interventions to reduce maternal and neonatal mortality in developing countries: systematic review and metaanalysis. BMC Pregnancy Childbirth. 2014;14:129.

\section{Publisher's Note}

Springer Nature remains neutral with regard to jurisdictional claims in published maps and institutional affiliations.

Ready to submit your research? Choose BMC and benefit from:

- fast, convenient online submission

- thorough peer review by experienced researchers in your field

- rapid publication on acceptance

- support for research data, including large and complex data types

- gold Open Access which fosters wider collaboration and increased citations

- maximum visibility for your research: over $100 \mathrm{M}$ website views per year

At $\mathrm{BMC}$, research is always in progress.

Learn more biomedcentral.com/submission 